\title{
Analysis of Structural and Non-Structural Disaster Mitigation Due to Erosion in the Timbulsloko Village, Demak - Central Java
}

\author{
Denny Nugroho Sugianto ${ }^{1,2,3^{*}}$, Rikha Widiaratih', Sugeng Widada4, \\ Suripin ${ }^{2}$, Elinna Putri Handayani ${ }^{1}$, Putri Cahyaningtyas ${ }^{1}$
}

1 Oceanography Department, Faculty of Fisheries and Marine Sciences, Universitas Diponegoro, Jl. Prof. Soedarto SH Tembalang, Semarang, 50275, Indonesia

${ }^{2}$ Laboratorium Ocean Modelling and Climate Change-UPT Integrated Laboratory, Universitas Diponegoro, J. Prof. Soedarto SH Tembalang, Semarang, 50275, Indonesia

${ }^{3}$ Center for Coastal Disaster Mitigation and Rehabilitation Studies, Universitas Diponegoro, Jl. Prof. Soedarto SH Tembalang, Semarang, 50275, Indonesia

${ }^{4}$ Civil Engineering Department, Faculty of Engineering, Universitas Diponegoro, J. Prof. Soedarto SH Tembalang, Semarang, 50275, Indonesia

* Corresponding author's e-mail: dennysugianto.oceanography@gmail.com

\begin{abstract}
Timbulsloko is a village on the coast of Sayung District, Demak Regency that is severely affected by coastal erosion. The coastal erosion in the Timbulsloko Village is mainly caused by the removal of mangrove areas, which has eliminated the function of the natural breakwater for the coast of the Timbulsloko Village. This study aimed to mitigate the coastal erosion in the form of structural and non-structural protection. Structurally (physically), mitigation is conducted by protecting the coastal area with the application of environmentally friendly coastal protection technology in the form of a Permeable breakwater with a Hybrid Engineering structure. Furthermore, the effectiveness of two different structure segments in damping waves from September 2020 - March 2021 will be measured. In contrast, non-structurally, mitigation is conducted in a non-physical way by analyzing the Coastal Vulnerability Index of Timbulsloko Village based on the parameters of Coastal Typology, Average Tidal Range, Significant Wave Height, Coastal Slope, Coastal Geomorphology, Sea Level Rises, and Shoreline Displacement using the CVI method. The effectiveness of the permeable structure's wave damping is determined by the initial wave height and transmission wave height measured by the ultrasonic sensor. On the basis of segment differences, the Permeable Breakwater Segment 2 with a distance between bamboo of $0.25 \mathrm{~m}$ has better effectiveness than a Permeable Breakwater Segment 1 with a distance between bamboo of $0.5 \mathrm{~m}$. The results of the Coastal Vulnerability Analysis show that the Timbulsloko Village is vulnerable to coastal disasters, especially coastal erosion.
\end{abstract}

Keywords: wave damping, permeable breakwater, coastal erosion, timbulsloko village, coastal vulnerability analysis, coastal vulnerable index.

\section{INTRODUCTION}

The North Coast of Java is a transitional area between the Java mainland with Alluvial morphology and the Java Sea which has calm waves. All processes that occur on land and at sea greatly affect the condition of the northern coast of Java. According to Ekosafitri et al. (2017), the northern coast of Java is an area that continues to experience coastline dynamism due to coastal erosion.
One of the areas on the North Coast of Java that experienced the highest level of erosion is the Timbulsloko Village, Demak Regency, Central Java Province. The erosion in the Timbulsloko Village is basically normal due to the type of muddy beach typology. However, this condition was exacerbated by the transfer of the function of mangrove forests to fishponds in 1980 around the Timbulsloko Village area, which had eliminated an area of about 4,248.85 ha per year (Romadhon, 
et al., 2014). This condition is very detrimental to the coastal communities living in the Timbulsloko Village due to the loss of land area to live and do activities. Therefore, a solution is needed to restore the environmental conditions of the Timbulsloko Village and reduce the negative impact of the erosion that occurs.

This study aimed to carry out disaster mitigation in the form of structural and non-structural preservation of the coastal environment. Structurally (physically), the mitigation of environmental degradation in the coastal areas is carried out by making protection for coastal areas, namely the application of environmentally friendly coastal protection technology in the form of Permeable breakwater with a Hybrid Engineering structure. In contrast, non-structurally, mitigation is carried out in a non-physical way, namely by analyzing the value of the Coastal Vulnerability Index of Timbulsloko Village using the CVI method. This mitigation technique is expected to reduce the impact of damage caused by coastal erosion and restore the environmental conditions in the Timbulsloko Village, Demak Regency, Central Java.

\section{MATERIAL AND METHODS}

The material in this study is divided into primary data and secondary data. The primary data was taken through observation at the research site, namely:

- Ocean wave height measurement data using Ultrasonic Sensors (Sept. 2020 - March 2021);

- Visual observation data of the coastal environment of Timbulsloko Village, Demak Regency;

- Ocean wave height measurement data using ADCP (29 Aug. - 1 Sept. 2020).

In turn, the secondary data is supporting data that is used to help analyze the main data in the form of open access data, namely:

- Sentinel-2A satellite image recording September 15, 2020;

- Digital elevation model (DEM) SRTM 30M Data 2018;

- Publication tidal data from BIG for 2020 -2021 ;

- Wind data of Ahmad Yani Airport Semarang in the year 2020-2021;

- Data on sea level rise in 2016-2020

- Coastline change rate data for 2016-2020.
The method used to determine the effectiveness of wave attenuation of permeable breakwater structures is the zero up-crossing method in which one wave height consists of a peak water level and a valley water level that passes through the still water level (SWL) (Triatmodjo, 1999). The tool used to determine the value of sea level is an ultrasonic sensor which is placed before and after the structure. The result of sea level height is then processed to obtain the wave height value. After the value of the wave height before and after the structure is obtained, then the value of the effectiveness of wave attenuation for each segment is determined by the equation:

$$
\left|\frac{H i-H t}{H i}\right| \times 100 \%
$$

where: $H t$ is the significant wave height after passing through the structure (transmission) $(\mathrm{cm})$ and $H i$ is the significant incoming wave height $(\mathrm{cm})$.

The method used to determine the value of coastal vulnerability in the Timbulsloko Village is the Coastal Vulnerablity Index method. The CVI method used is based on the parameters of Coastal Typology (Ti), Average Tidal Range (TR), Significant Wave Height (G), Coastal Slope (Ki), Coastal Geomorphology (GF), Sea Level Rise (KMR), and Coastline Change (PGP). After the parameters are determined, the second step is processing the acquisition of coastal vulnerability index parameters:

- Coastal typology data is obtained from the results of field documentation which is then scored on the vulnerability table.

- Average tidal range data is processed using the Least Square method in the Matlab software to determine the Mean Highest Water Level (MHWL), Mean Water Level (MWL), Average-Mean Lowest Water Level (MHWL), and Tidal Range.

- Data of Significant Wave Height is processed by wave forecasting with the DNS method which is verified using the ADCP wave data. The predicted wave height is then sorted from the highest to the lowest value; subsequently, the average wave height is determined from one third of the highest wave height. Thus, a significant wave height value is obtained.

- Coastal Slope data was processed from the DEM SRTM $30 \mathrm{M}$ data using the ArcGIS software to generate slope values for Timbulsloko Village. 
- Coastal Geomorphological Data was processed using Sentinel-2A Satellite Imagery which was digitized on ArcGis software.

- Data on sea level rise is obtained from Primasti's research (2021). The results obtained are then scored against the vulnerability table.

- Shoreline Change Data obtained from Primasti's research (2021). The results obtained are then scored against the vulnerability table.

The next step is to score the results of each parameter based on the vulnerability table (Table 1). The results of the scoring are then analyzed to determine the level of vulnerability of the coast of the Timbulsloko Village to coastal disasters. This scoring table refers to Gornitz (1991), which is then modified according to the coastal conditions of the Timbulsloko Village.

According to Gornitz $(1990,1991)$ by aligning the various parameters to be measured, the Coastal Vulnerability Index using the CVI method can be calculated based on the equation:

$$
C V I=\sqrt{\frac{(\mathrm{Ty} \times \mathrm{W} \times \mathrm{Tr} \times \mathrm{S} \times \mathrm{GF} \times \mathrm{SLR} \times \mathrm{Sd})}{5}}
$$

where: Ty - Coastal Typology Index, S - Coastal Slope Index, W - Significant Wave Height Index, GF - Coastal Gemorphology Index, $\mathrm{Tr}$ - Tidal Range Index, Sd - Shoreline Displacement Index, SLR Sea Level Rise Index, CVI - Coastal Vulnerable Index.

After the calculation results were obtained, the total CVI range was divided into four equal parts based on the 33rd percentile range, and the highest value or CVI $>33.0$ was taken as the very high-risk shoreline (Gornitz, 1991). The overall nature of the vulnerability is shown in Table 2.

\section{RESULTS AND DISCUSSION}

\section{Sea level measurement using ultrasonic sensors}

Measurement of sea level using ultrasonic sensors produces water level height according to the tidal phase that forms a sinusoidal wave. The results of the measurement of sea level (y) are then plotted with the recording time $(t)$ to see the distribution pattern of the results of sea level measurements during high and low tide conditions.

On the basis of the graphs generated from sea level measurements, there are some data that are outside the tidal and low tide phases that form sinusoidal waves. The data is noise data or the noise data recorded by ultrasonic sensors. The highest amount of noise data is in September, October, and November 2020, which is the second transition season. The large amount of noise data can be caused by strong winds and heavy rains that occur continuously in September - November 2020. This is corroborated by the fact announced by the World Meteorological Organization that there has been a La Nina climate anomaly that has occurred since August 2020 with peak around October - December 2020 (WMO, 2020).

Table 1. Scoring of coastal vulnerability physical parameters

\begin{tabular}{|c|c|c|c|c|c|c|}
\hline \multirow{3}{*}{ No } & \multirow{3}{*}{ Parameters } & \multicolumn{5}{|c|}{ Coastal Vulnerability Index Class } \\
\hline & & Very low & Low & Moderate & High & Very high \\
\hline & & 1 & 2 & 3 & 4 & 5 \\
\hline 1 & Coastal typology $y^{(2)}$ & coral beach & rocky beach & $\begin{array}{l}\text { sandy and } \\
\text { muddy beach }\end{array}$ & sandy beach & muddy beach \\
\hline 2 & Tidal range (in meter) ${ }^{(3)}$ & $\begin{array}{c}\leq 0.99 \\
\text { micro-tidal }\end{array}$ & $1.0-1.9$ & $\begin{array}{c}1.0-4.0 \\
\text { meso-tidal }\end{array}$ & $4.1-6.0$ & $\begin{array}{c}\geq 6.1 \\
\text { macro-tidal }\end{array}$ \\
\hline 3 & Significant wave height $(m)^{(1)}$ & $<0.55$ & $0.55-0.85$ & $0.85-1.05$ & $1.05-1.25$ & $>1.25$ \\
\hline 4 & Coastal slope ${ }^{(4)}$ & $>45 \%$ & $25-45 \%$ & $15-25 \%$ & $8-15 \%$ & $0-8 \%$ \\
\hline 5 & Coastal geomorphology ${ }^{(5)}$ & $\begin{array}{l}\text { rocky, cliffed } \\
\text { coasts, fiords }\end{array}$ & $\begin{array}{l}\text { medium cliffs, } \\
\text { indented coasts }\end{array}$ & $\begin{array}{c}\text { low cliffs, } \\
\text { glacial drift, } \\
\text { alluvial plains }\end{array}$ & $\begin{array}{c}\text { cobble } \\
\text { beaches, } \\
\text { estuary, lagoon }\end{array}$ & $\begin{array}{l}\text { barrier beaches, } \\
\text { sand beaches, salt } \\
\text { marsh, mud flats, } \\
\text { deltas, mangrove, } \\
\text { coral reefs }\end{array}$ \\
\hline 6 & Sea level rise $(\mathrm{mm} / \mathrm{year})^{(3)}$ & $\begin{array}{c}\leq-1.1 \\
\text { accretion }\end{array}$ & $-1.0-0.99$ & $\begin{array}{l}1.0-2.0 \\
\text { stable }\end{array}$ & $2.1-4.0$ & $\begin{array}{c}\geq 4.1 \\
\text { erosion }\end{array}$ \\
\hline 7 & Shoreline displacement (m/year) ${ }^{(3)}$ & $\geq 2.1$ & $1.0-2.0$ & $(-1.0)-1.0$ & $-1.1-(2.0)$ & $\leq-2.0$ \\
\hline
\end{tabular}

Source: Joesidawati (2016) ${ }^{(1)}$; Arini, et al. (2014) ${ }^{(2)}$; Gornitz $(1990,1991)^{(3)}$; Directorate General of Reforestation and Land Rehabilitation (Indonesia) (1986)(4); Thieler and Hammar-Klose, 2000 ${ }^{(5)}$. 
Table 2. Final scoring of coastal vulnerability physical parameters

\begin{tabular}{|c|c|l|}
\hline No & CVI Value & \multicolumn{1}{|c|}{ CVI Description } \\
\hline 1 & $\leq 11$ & Not vulnerable \\
\hline 2 & $>11-22$ & Moderate \\
\hline 3 & $>22-33$ & Vulnerable \\
\hline 4 & $\geq 33$ & Very vulnerable \\
\hline
\end{tabular}

Source: Gornitz (1991).

\section{Wave height measurement based on water level results}

The graph of the sea level correction results shows that for every change in measurement time there are small sinusoidal waves that form peaks and valleys in the measurement of sea level height. This small sinusoidal wave in the tidal phase is then processed into a wave value. The data selected to be processed into wave values were analyzed using Fourier Analysis in Matlab to eliminate the noise data or further data noise from the results of sea level height values. After the Fourier analysis, the wave height is searched by determining the difference between the peak and the trough of the wave, and the value of the wave period is found by determining the length of time the wave travels from the crest to the crest or the trough to the trough. The results obtained from this measurement are the value of the height and period of the waves both before and after passing the structure in segment 1 and segment 2.

On the basis of the on the graph of the results of the Fourier analysis on all data, it can be seen that the average wave at high tide is higher than the wave at low tide. This is because sea water can only touch the Permeable Breakwater area to the maximum during high tide. According to
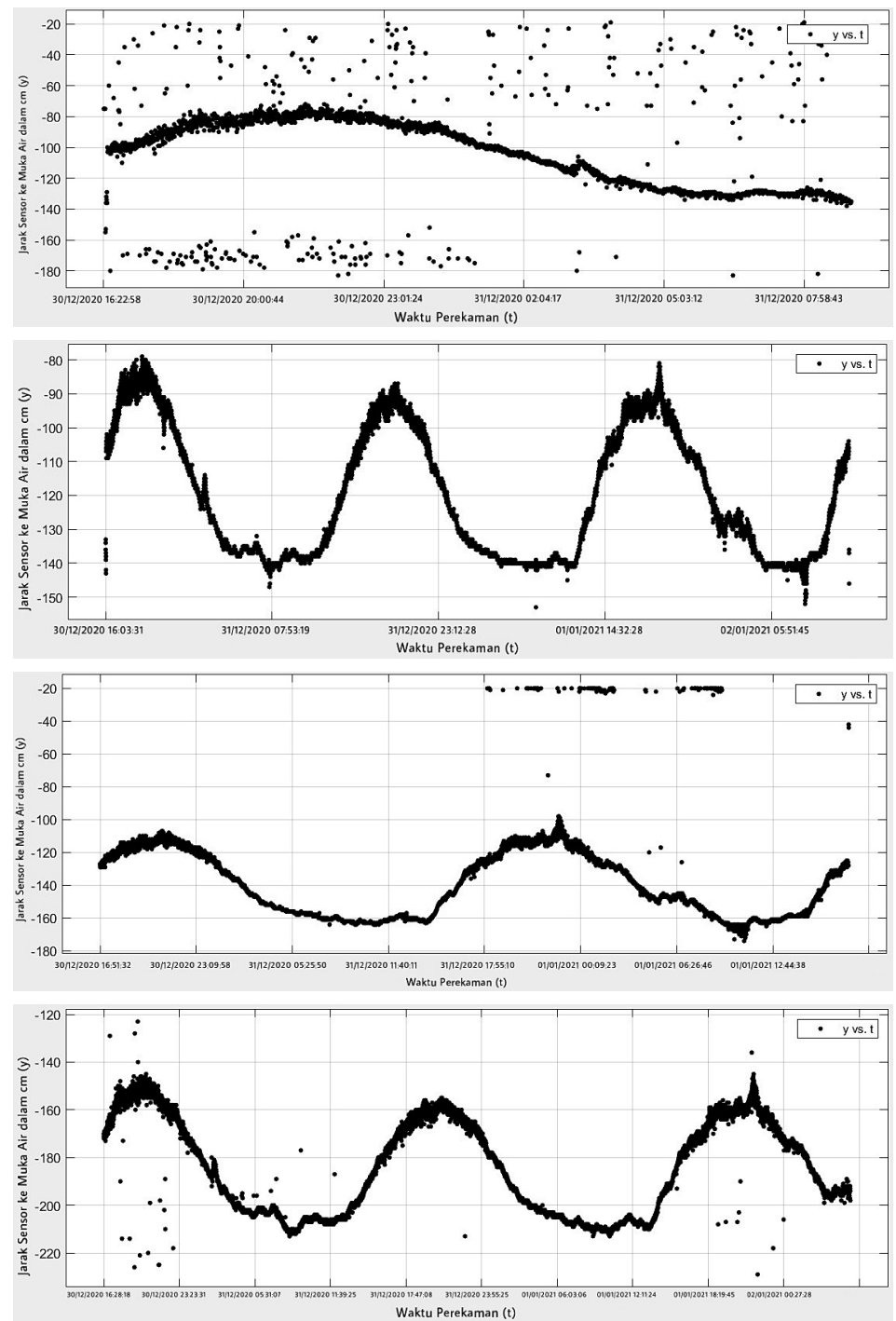

Figure 1. Sample result of sea level measurement graph 30 December 2020 - 2 January 2021 


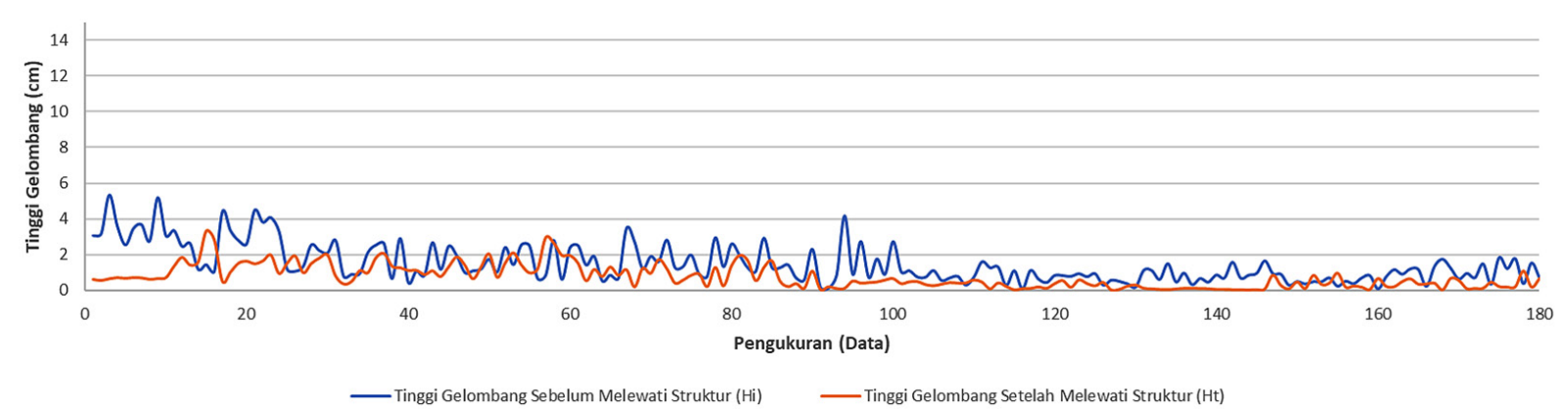

Figure 2. Sample result of the graph of difference in wave height measurements before and after passing the segment structure 1 measurement 30-31 December 2020

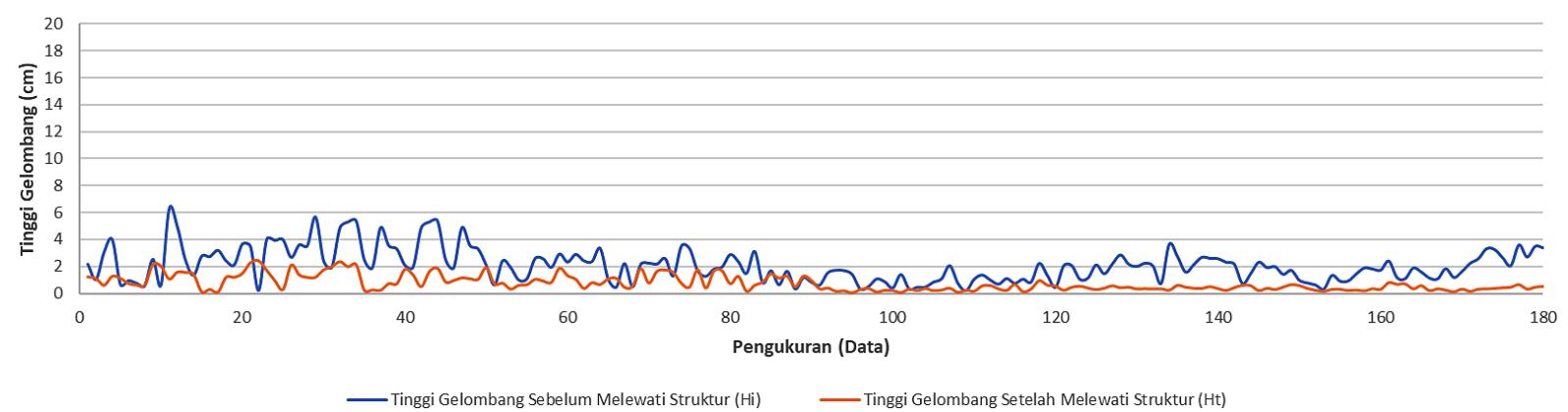

Figure 3. Sample result of the graph of difference in wave height measurements before and after passing the segment structure 2 measurements 30-31 December 2020

Munk (1951) in Sugianto (2010), the waves in the Timbulsloko Village have the characteristics of waves generated by the wind, so that the magnitude of the wind value greatly affects the magnitude of the wave height. Strong winds will generate higher waves. On the basis of statistical results, the wave height value in September - December 2020 has a higher value than the wave height value in January - March 2021. This is in line with the time of the La Nina phenomenon. Furthermore, it can be concluded that the wave height values studied are closely related to the La Nina climate anomaly which causes extreme weather including strong winds.

The difference in the value of the incident wave (Hi) in segment 1 and segment 2 is caused by the difference in the location of the two segments. The waves coming towards segment 1 have been damped by the mangroves on the left and the Permeable Breakwater in front, while the waves coming towards segment 2 are larger because they are closer to the position of the gap between the Permeable Breakwater and the pond as a direct entry point for sea water. enter without being muffled by any obstruction. The difference in the location of the two segments makes the value of the incident wave (Hi) in segment 2 greater than the value of the incident wave in segment 1 .

\section{Effectiveness of wave damping on permeable breakwater}

The value of the effectiveness of wave attenuation is a quantity that describes the ability of the Hybrid Engineering structure as a permeable breakwater in reducing the incoming wave height. The damping effectiveness value is tested on each Permeable Breakwater segment.

On the basis of the results obtained, Permeable Breakwater can dampen waves more effectively in September 2020 - December 2020 than in January - March 2021. According to Iskandar (2018), the permeable structure will dampen waves well when the incoming wave height is becoming smaller. However, the results of the study show that the Permeable Breakwater can be more optimal in dampening the waves in September - December 2020 which has a higher wave height value than January - March 2021. This can be because the Permeable Breakwater conditions in September - December 2020 are more optimal, where the condition of the branches and structure is still very good and sturdy, so that it can dampen the waves optimally. Meanwhile, the condition of the structure in January - March 2021 suffered significant damage as a result of the increase in rainfall and extreme 


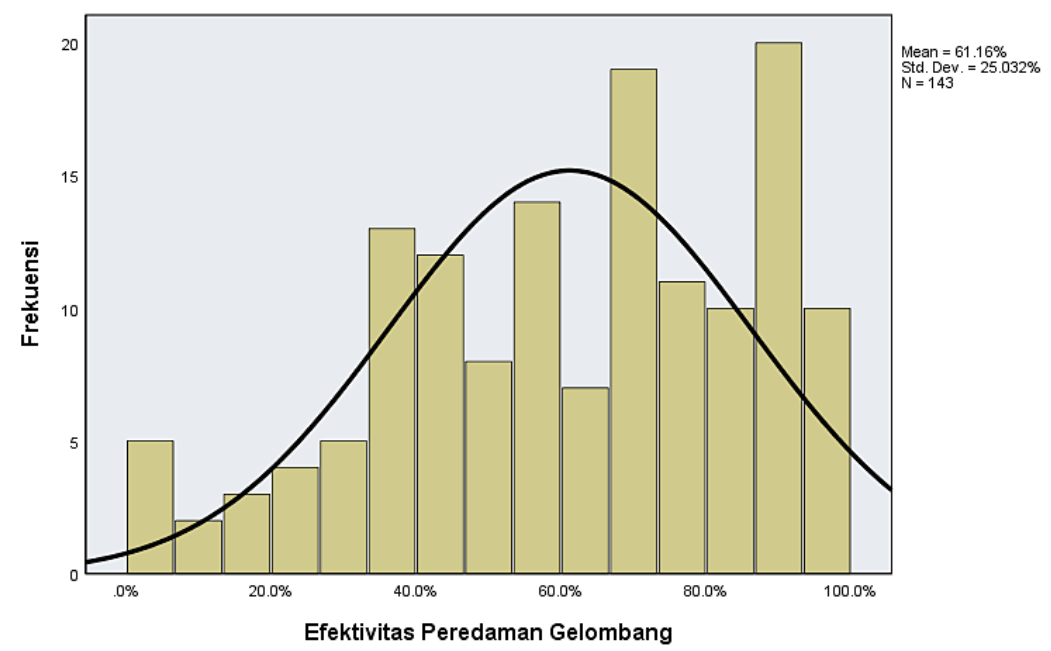

Figure 4. Sample result of the graph and table of event frequency effectiveness of segment 1 wave damping measurement December 30-31, 2020

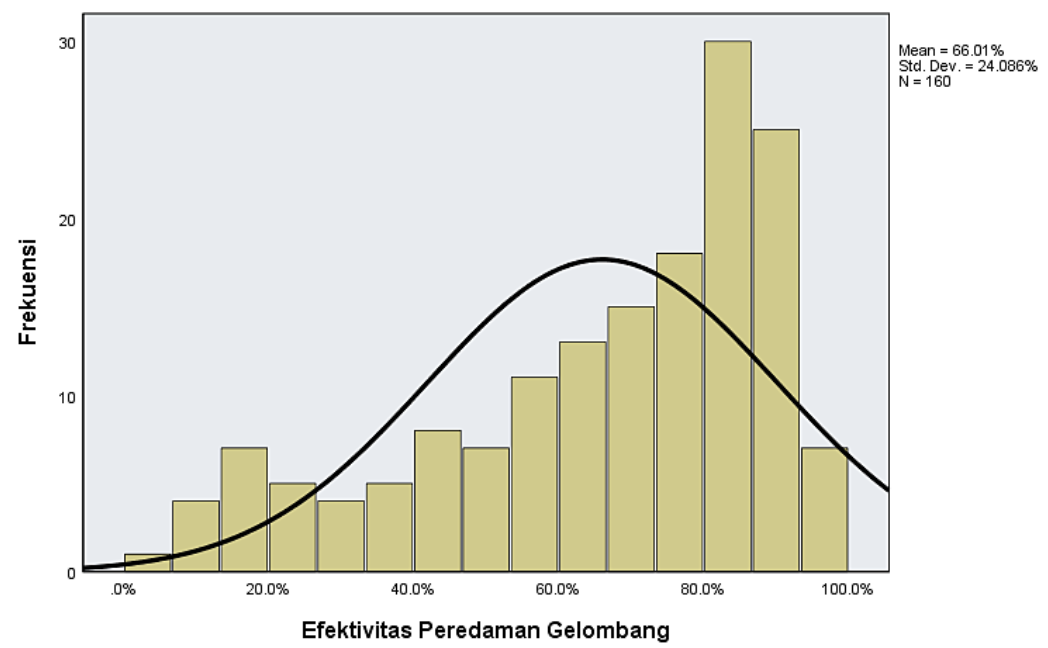

Figure 5. Sample result of the graph and table of event frequency effectiveness of segment 2 wave damping measurement December 30-31, 2020

weather that occurred in September - December 2020 so that the Permeable Breakwater's ability to dampen waves was weakened.

On the basis of the results of statistical processing of the effectiveness of Permeable Breakwater damping, segment 2 has generally a higher average value of wave attenuation effectiveness than segment 1 . This is in line with the bamboo density theory where segment 2 has a bamboo density value of $0.25 \mathrm{~m}$, while segment 1 has a density value of $0.5 \mathrm{~m}$. The closer distance between the bamboos will strengthen the structure of the Permeable Breakwater, so that it can further optimize the function of the twigs in dampening the waves. This is what makes segment 2 with a closer distance between bamboos can absorb waves better than segment 1 in the Permeable Breakwater structure.

\section{Coastal vulnerable index}

On the basis of the results of the survey and processing of all data, an analysis of the coastal area of the Timbulsloko Village was obtained from all parameters. The Timbulsloko village has a type of beach typology in the form of a muddy beach. Muddy beaches have very small sediment grain sizes so that they can be easily carried by currents from one place to another. The easier it is for the sediment in a location to move, the easier it is for that location to experience changes in coastal morphology. The Timbulsloko village has a very low mean tidal range of $0.38 \mathrm{~m}$. The lower the value of the tidal range, the lower the tidal current velocity that occurs, so that the ability to erode and transport sediment to change the morphology of the beach is also small. The 

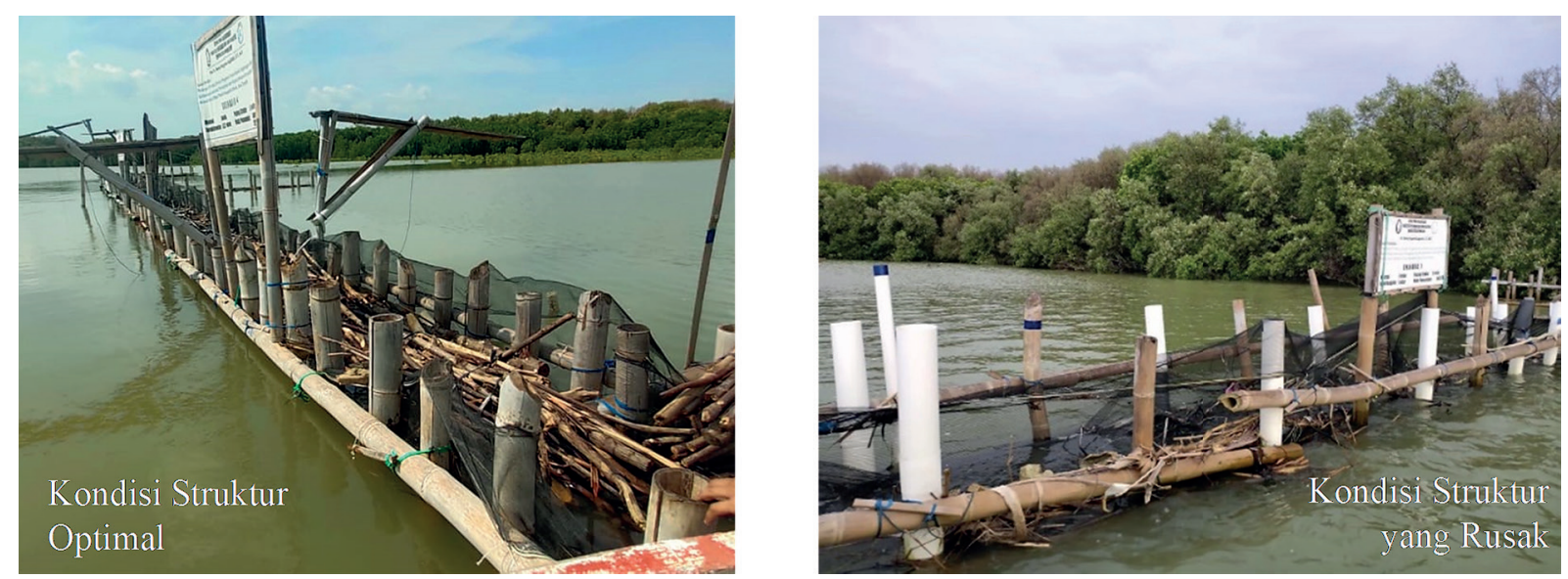

Figure 6. Permeable breakwater structural damage condition

Timbulsloko village has a low significant wave height value of $0.57 \mathrm{~m}$. The lower the wave value in an area, the lower the possibility of danger that occurs due to the erosion / beach erosion process because the energy given in the coastal erosion process is decreasing. The Timbulsloko village has a coastal slope value of $0-8 \%$ which is included in the type of beach slope that is flat or very gentle. The lower the value of the beach slope (sloping coast), the wider the beach area that will be inundated when there is a change in sea level rise. It is the loss of land or land due to inundation which causes sloping beaches to more easily experience coastline decline. HammarKlose et al. (2003) also explained that sloping beaches are more susceptible to sediment particle displacement as the main component of forming a beach profile compared to steeper beaches. Sloping beaches tend to have sediment grains that are continuously going back and forth due to being exposed to standing water, so that they are easily broken into smaller pieces. The phenomenon of puddles that easily occurs on sloping beaches makes smaller sediments more easily carried by the water, so that the movement of sediment particles will occur more easily, which can eventually change the shape of the beach morphology. The geomorphology of the coast in the Timbulsloko Village is filled with mangrove vegetation and at some points there are areas directly adjacent to settlements. On the basis of the results of coastal slope data processing, it can be seen that the Timbulsloko Village has a gentle slope. Then, based on Coastal Typology data, it can be seen that the Timbulsloko Village has a type of muddy coastal sediment. All data that has been processed shows that the Timbulsloko Village has a Coastal Geomorphology in the form of exposure to mud and mangroves which are very vulnerable to coastal disasters. The sloping and muddy coastal geomorphology is very susceptible to inundation and coastal erosion. The value of sea level rise in the Timbulsloko Village reaches $7.9 \mathrm{~mm} /$ year. The areas with high sea level rise values are very vulnerable to the impact of wider inundation and faster coastal erosion processes. The sea water that can reaches land areas further will erode the mud sediments in the Timbulsloko Village so that the erosion process will be faster. The high value of sea level rise also plays a major role in the permanent inundation process which can eliminate most of the land in the Timbulsloko Village, because it turns into part of the ocean. On the basis of the data on the rate of shoreline change, the coastal area of the Timbulsloko Village experienced severe coastal erosion, reaching -50.51 $\mathrm{m} / \mathrm{year}$. The high erosion value causes the land of the Timbulsloko Village to be eroded by sea water continuously, so that rising sea levels will have a greater impact on the inundation area in

Table 3. Timbulsloko village coastal vulnerability index calculation results

\begin{tabular}{|c|c|c|c|c|c|c|c|c|c|c|}
\hline \multirow[b]{2}{*}{ No } & \multicolumn{8}{|c|}{ Scoring } & \multirow[b]{2}{*}{$\begin{array}{c}\mathrm{CVI} \\
\text { description }\end{array}$} & \multirow[b]{2}{*}{ CVI colour } \\
\hline & $\begin{array}{l}\text { Coastal } \\
\text { typology }\end{array}$ & $\begin{array}{l}\text { Tidal } \\
\text { range }\end{array}$ & $\begin{array}{c}\text { Significant } \\
\text { wave } \\
\text { height }\end{array}$ & $\begin{array}{l}\text { Coastal } \\
\text { slope }\end{array}$ & $\begin{array}{c}\text { Coastal } \\
\text { geomorphology }\end{array}$ & $\begin{array}{l}\text { Sea level } \\
\text { rise }\end{array}$ & $\begin{array}{c}\text { Shoreline } \\
\text { displacement }\end{array}$ & $\begin{array}{c}\text { CVI } \\
\text { value }\end{array}$ & & \\
\hline 1 & 5 & 1 & 2 & 5 & 5 & 5 & 5 & 29.88 & Vulnerable & \\
\hline
\end{tabular}




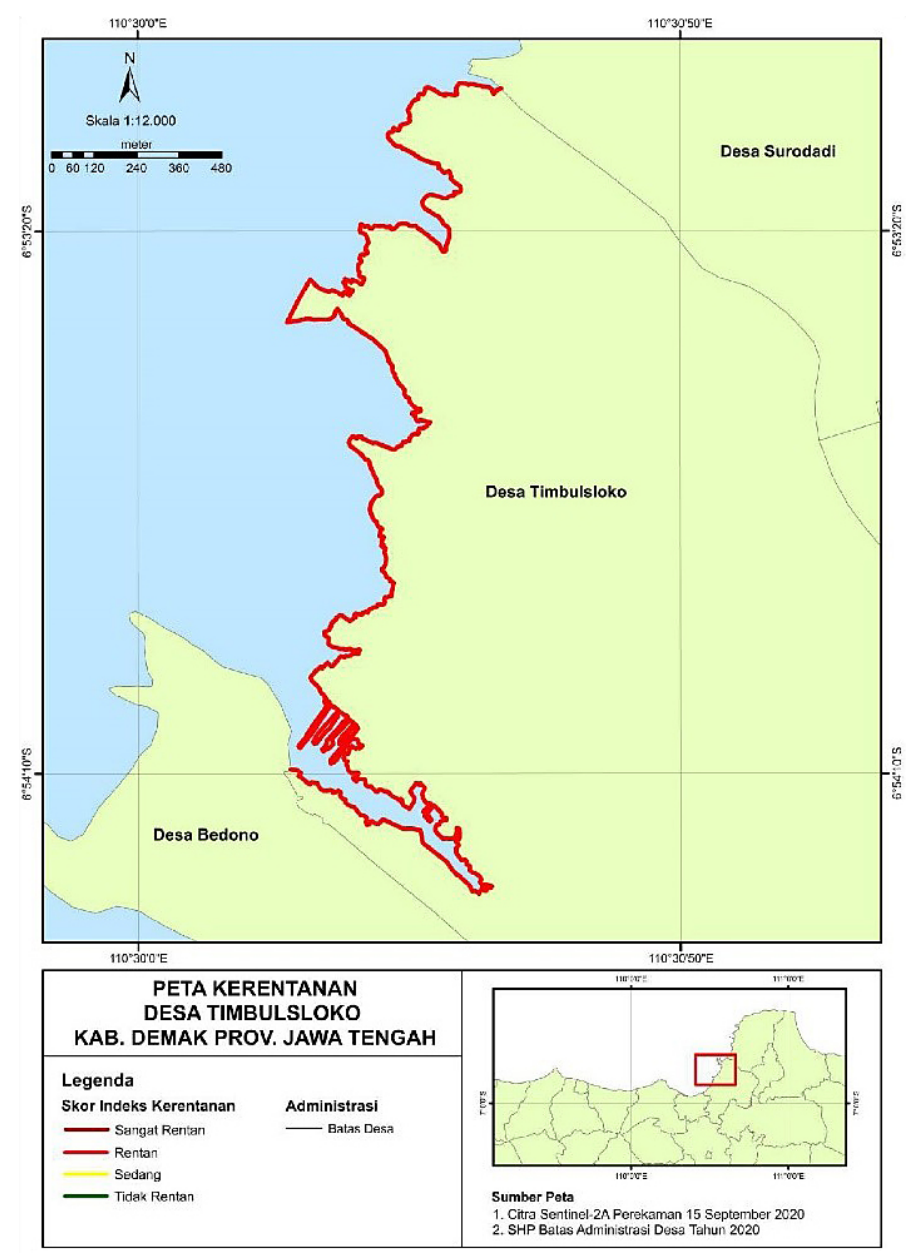

Figure 7. Timbulsloko Village coastal vulnerability map

the Timbulsloko Village. Therefore, the high erosion rate will result in the loss of more land in the Timbulsloko Village due to sea level rise.

The results and analysis of the vulnerability parameters were then calculated using the CVI equation to obtain the value of the coastal vulnerability of the Timbulsloko Village, which is presented in Table 3. On the basis of the Timbulsloko Village Beach Vulnerability Index, the entire Timbulsloko Village Beach is an area that is vulnerable to coastal disasters when viewed from the beach typology parameters, tidal range low tide, significant wave height, beach slope, coastal geomorphology, sea level and shoreline changes in the Timbulsloko Village. Coastal disasters that are prone to occur in the Timbulsloko Village are mainly coastal erosion and tidal flooding. This coastal vulnerability index shows that the Timbulsloko Village is in dire need of effective and efficient mitigation to reduce the magnitude of the impact caused by the coastal disaster. One of the mitigations that can be done is by making a permeable breakwater in an environmentally friendly
Hybrid Engineering approach. This structure can assist in dampening the waves, as well as capturing sediment carried by the waves. The sediment that is caught is expected to settle and over time can create sedimentation areas to bring back the areas that have been lost due to coastal erosion and permanent inundation, so that the impacts caused by coastal disasters can be reduced effectively and efficiently.

\section{CONCLUSIONS}

On the basis of the research that has been done, Permeable Breakwater structure as the structural disaster mitigation has a higher Wave Damping Effectiveness in September - December 2020 compared to January - March 2021 due to optimal structural conditions. Then, based on the different segments, the Permeable Breakwater Structure Segment 2 with a distance between bamboo of $0.25 \mathrm{~m}$ has a better Wave Damping Effectiveness value than the Permeable Breakwater Segment 1 
structure with a bamboo density distance of 0.5 $\mathrm{m}$, because it has a stronger sediment-holding ability. As the non-structural disaster mitigation, The Coastal Vulnerability lndex of Timbulsloko Village based on the parameters of Coastal Typology, Tidal Range Height, Significant Wave Height, Coastal Slope, Coastal Geomorphology, Sea Level Rise, and Shoreline Change using the CVI method is in the Vulnerable class with a CVI value of 29.88 .

\section{Acknowledgements}

Extend gratitude to Oceanography Department Universitas Diponegoro, Laboratorium Ocean Modelling and Climate Change-UPT Integrated Laboratory, Universitas Diponegoro, LPPM Universitas Diponegoro, Center for Coastal Rehabilitation and Disaster Mitigation Studies (CoREM-PKMBRP) - Center of Excellence Science and Technology (PUI), and Ministry of Education and Culture Republic of Indonesia for funding our research with grant number 257-104/ UN7.6.1/PP/2021.

\section{REFERENCES}

1. Ekosafitri K.H., Rustiadi E., dan Yulianda F. 2017. Pengembangan Wilayah Pesisir Pantai Utara Jawa Tengah Berdasarkan Infrastruktur Daerah: Studi Kasus Kabupaten Jepara. Journal of Regional and Rural Development Planning, 1(2), 145-157.
2. Gornitz V. 1991. Global Coastal Hazards from Future Sea Level Rise. Palaeogeogr. Palaeoclimatol. Palaeoecol, 89, 379-398.

3. Gornitz V.M. 1990. Vulnerability of The East Coast, U.S.A. To Future Sea Level Rise. J. Coast. Res. Special Issue, 9, 201-237.

4. Hammar-Klose E.S., Pendleton E.A., Thieler E.R., dan S.J. Williams. 2003. Coastal Vulnerability Assessment of Cape Cod National Seashore (CACO) To Sea-Level Rise. USGS Report. 23.

5. Primasti, Gustya T.P., Hariyadi, Rochaddi B., Widada S., Widiaratih D.R. 2021. Pemantauan Kerentanan Fisik di Pesisir Kabupaten Demak (Studi Kasus Perubahan Garis Pantai). Indonesian Journal of Oceanography, 3(1).

6. Romadhon, Ahmad, Hastuti D., Prabowo D.R. 2014. Pengaruh Rob dan Abrasi Terhdap Pendapatan Petani Tambak Bandeng. Mediagro, 10(1), 69-81.

7. Sugianto D.N. 2010. Model Distribusi Data Kecepatan Angin dan Pemanfaatanya dalam Peramalan Gelombang di Perairan Laut Pacitan Jawa Timur. Journal Ilmu Kelautan, 15(3), 143-152.

8. Thieler E.R., Hammar-Klose E.S. 2000. National Assessmen t of Coastal Vulnerability to Sea-Level Rise: U.S. Pacific Coast. U.S. Geological Survey, Open-File Report 00-178, http://pubs.usgs.gov/ of/2000/of00-178/ (accessed July 24, 2021)

9. Triatmodjo, Bambang. 1999. Teknik Pantai. Beta Offset. Yogyakarta.

10. World Meteorological Organization (WMO). 2020. El Niño / La Niña Southern Oscillation (ENSO). https://public.wmo.int/en/our-mandate/climate/ el-ni\%C3\%B1ola-ni\%C3\%B1a-update (accessed May 24, 2021) 